\title{
Surface Detail Reproduction and Dimensional Accuracy of Stone Models: Influence of Disinfectant Solutions and Alginate Impression Materials
}

\author{
Ricardo Danil GUIRALDO ${ }^{1}$ \\ Thaís Teixeira BORSATO ${ }^{1}$ \\ Sandrine Bittencourt BERGER ${ }^{1}$ \\ Murilo Baena LOPES $^{1}$ \\ Alcides GONINI-Jr ${ }^{1}$ \\ Mário Alexandre Coelho SINHORETI ${ }^{2}$ \\ ${ }^{1}$ Department of Restorative Dentistry, Dental School, UNOPAR - University North of Parana, Londrina, PR, Brazil \\ ${ }^{2}$ Department of Restorative Dentistry, Piracicaba Dental School, \\ UNICAMP - University of Campinas, Piracicaba, SP, Brazil
}

\begin{abstract}
This study compared the surface detail reproduction and dimensional accuracy of stone models obtained from molds disinfected with $2 \%$ sodium hypochlorite, $2 \%$ chlorhexidine digluconate or $0.2 \%$ peracetic acid to models produced using molds which were not disinfected, with 3 alginate materials (Cavex ColorChange, Hydrogum 5 and Jeltrate Plus). The molds were prepared over matrix containing 20-, $50-$, and $75-\mu \mathrm{m}$ lines, performed under pressure with perforated metal tray. The molds were removed following gelation and either disinfected (using one of the solutions by spraying followed by storage in closed jars for $15 \mathrm{~min}$ ) or not disinfected. The samples were divided into 12 groups $(\mathrm{n}=5)$. Molds were filled with dental gypsum Durone IV and $1 \mathrm{~h}$ after the start of the stone mixing the models were separated from the tray. Surface detail reproduction and dimensional accuracy were evaluated using optical microscopy on the $50-\mu \mathrm{m}$ line with $25 \mathrm{~mm}$ in length, in accordance with the ISO 1563 standard. The dimensional accuracy results (\%) were subjected to ANOVA. The $50 \mu \mathrm{m}$-line was completely reproduced by all alginate impression materials regardless of the disinfection procedure. There was no statistically significant difference in the mean values of dimensional accuracy in combinations between disinfectant procedure and alginate impression material $(\mathrm{p}=0.2130)$ or for independent factors. The disinfectant solutions and alginate materials used in this study are no factors of choice regarding the surface detail reproduction and dimensional accuracy of stone models.
\end{abstract}

Key Words: surface detail reproduction, dimensional accuracy, disinfectant solution, alginate.

\section{INTRODUCTION}

Disinfection of tools and materials is an important step in dental procedures (1-3). In the absence of disinfection, treatment procedures can expose dentists, hygienists and laboratory workers to direct or crosscontamination $(4,5)$. Impression materials are used in dentistry to make accurate casts of oral tissues. They must be capable of recording the anatomic topography of the desired area and remain dimensionally stable. During the impression procedure, the materials come into contact with fluids such as blood and saliva, which may contain pathogenic microorganisms. Infectious diseases such as herpes, hepatitis, tuberculosis or AIDS may be transmitted during this process $(5,6)$.

Disinfectants must be effective as antimicrobial agents while not adversely affecting the dimensional accuracy or feature fidelity of the impression material and the resulting gypsum cast (7). The American Dental Association (ADA) recommends that alginate impressions be sprayed with an ADA-approved disinfectant and then sealed in a plastic bag for the recommended disinfection time $(1,2)$. Spray disinfection of alginate impressions with $1 \%$ sodium hypochlorite ( $\mathrm{NaOCl})$ or $2 \%$ glutaraldehyde reportedly did not cause adverse dimensional changes or surface deterioration of stone models produced from the impressions $(2,8)$. Moreover, the amount of water absorption and possible

Correspondence: Dr. Ricardo Danil Guiraldo, Faculdade de Odontologia, UNOPAR, Rua Marselha, 183, 86041-140 Londrina, PR, Brasil. Tel: +5543-3371-7820. Fax: +55-43-3341-8122. e-mail: rdguiraldo@gmail.com 
dimensional changes arising from the absorption varies with disinfectant concentration and type (8). Disinfection should be carried out with a product that requires the least amount of time for the disinfection process $(9,10)$. Thus, other potential disinfectants to eliminate pathogens could be used, provided that they do not alter the properties of alginate materials.

Alginates are commonly used as a two-component system - powder and water. The powder contains sodium or potassium alginates (soluble alginates), diatomaceous earth acting as filler particles, calcium sulfate as reactor, a fluoride as accelerator and sodium phosphate as a retarder (11). The surface detail reproduction and dimensional accuracy properties are necessary for a true copy of the molded anatomical structures. Thus, those properties are being used to analyze this ability of the impression materials (7). A previous study reported that the dimensional change of alginate impressions in 100\% relative humidity varied with the brand of impression material (8). However, molds are generally filled with plaster as quickly as possible, avoiding long exposure to air and the resulting syneresis and evaporation. If immediate casting is not possible, it is recommended that the mold be kept in a $100 \%$ relative humidity environment to preserve the water balance within the material. Many alginate manufacturers recommend that the models be cast within $12 \mathrm{~h}$ since increased dimensional change occurs after 12-24 h (12).

This study evaluated the surface detail reproduction and dimensional accuracy of stone models obtained from molds prepared using different alginate impression materials and disinfected using $2 \% \mathrm{NaOCl}$, $2 \%$ chlorhexidine digluconate $(\mathrm{CHX})$ or $0.2 \%$ peracetic acid compared with stone models produced from molds that were not disinfected. The null hypotheses tested were that the surface detail reproduction and dimensional accuracy of stone models are not affected by the alginate impression material or the disinfectant solution.

\section{MATERIAL AND METHODS}

The alginate impression materials Cavex ColorChange (Cavex Holland BV, Haarlem, The Netherlands), Hydrogum 5 (Zhermack, Badia Polesine, RO, Italy) and Jeltrate Plus (Dentsply Caulk, Milford, DE, USA) were used in this study.

The dimensional accuracy and surface detail reproduction were evaluated in accordance with the ISO 1563 standard (13). The molds were prepared over a matrix (38 $\mathrm{mm}$ outer diameter and $29.97 \mathrm{~mm}$ internal diameter) containing three parallel lines 20,50, and 75 $\mu \mathrm{m}$ wide and $25 \mathrm{~mm}$ in length and spaced $2.5 \mathrm{~mm}$ apart. Two additional lines marked $\mathrm{X}$ and $\mathrm{X}^{\prime}$ were used to determine the dimensional accuracy and surface detail reproduction on the $50 \mu \mathrm{m}$ line (Fig. 1).

Before performing the impression procedure, the matrix was ultrasonically cleaned and dried with compressed air. The alginate impression materials were prepared in accordance with the manufacturer's instructions. A perforated metal tray $(31 \mathrm{~mm}$ internal diameter, $5 \mathrm{~mm}$ high) was placed on a glass plate and filled with the molding material. The tray was joined to the matrix and a pressure of $2 \mathrm{kgf}$ was applied using a pneumatic press to simulate the impression process and allow for leakage of excess material (5).

The molds were removed $1 \mathrm{~min}$ after gelation (the gelation time was consistent with the minimum time recommended by the manufacturers) and disinfected using 2\% $\mathrm{NaOCl}$ (Qboa; Indústria Anhembi S/A, Osasco, SP, Brazil), 2\% CHX (Villevie clorhexidina; Dentalville do Brasil Ltda., Joinvile, SC, Brazil) or $0.2 \%$ peracetic acid (Peradesin; Ecoper Química LTDA, Mairiporã, SP, Brazil). Control samples were not disinfected. Disinfection consisted of spraying the samples with one of the solutions, covering with moist gauze, and sealing in closed jars at $100 \%$ relative humidity and $37{ }^{\circ} \mathrm{C}$ for $15 \mathrm{~min}$. The samples were divided into 12 groups $(\mathrm{n}=5)$ according to disinfectant procedure and

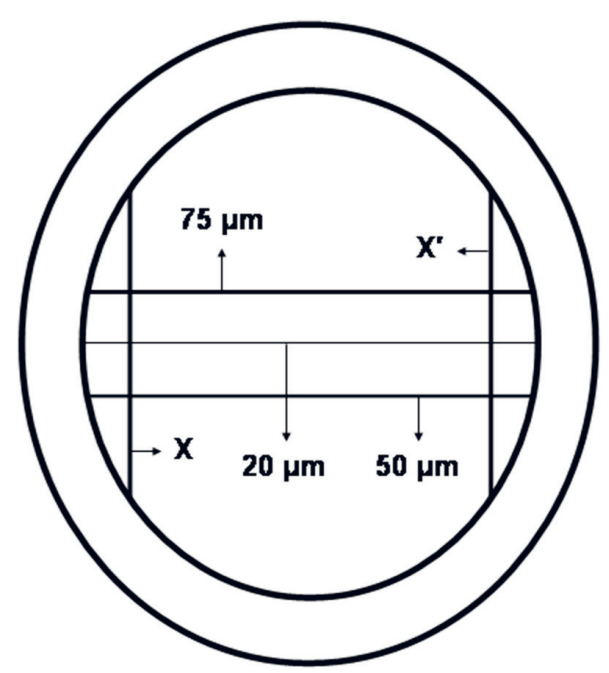

Figure 1. Schematic representation of apparatus (matrix) for measurement of surface detail reproduction and dimensional accuracy in accordance with ISO 1563. 
alginate impression material: Group 1: No disinfectant (control group) + Jeltrate Plus; Group 2: No disinfectant (control group) + Cavex ColorChange; Group 3: No disinfectant (control group) + Hydrogum 5; Group 4: $2 \% \mathrm{NaOCl}+$ Jeltrate Plus; Group 5: $2 \% \mathrm{NaOCl}+\mathrm{Cavex}$ ColorChange; Group 6: $2 \% \mathrm{NaOCl}+$ Hydrogum 5; Group 7: 2\% CHX + Jeltrate Plus; Group 8: 2\% CHX+ Cavex ColorChange; Group 9: 2\% CHX + Hydrogum 5; Group 10: 0.2\% Peracetic acid + Jeltrate Plus; Group 11: $0.2 \%$ Peracetic acid + Cavex ColorChange; and Group 12: $0.2 \%$ Peracetic acid + Hydrogum 5.

The disinfected and control molds were rinsed with $150 \mathrm{~mL}$ of distilled water, dried and filled with gypsum plaster (Durone IV; Dentsply Caulk) $15 \mathrm{~min}$ and immediately after impression, respectively. The stone models were separated from the tray containing the alginate $1 \mathrm{~h}$ after the start of the stone mixing.

Measurements of surface detail reproduction were performed using an optical microscope (SZM; Bel Engineering srl, MI, Italy). The stone models were examined under low-angle illumination at magnifications of $\times 4$ to $\times 12$ to determine whether the $50 \mu \mathrm{m}$-line was completely reproduced over the full 25 $\mathrm{mm}$ length between the intersecting reference lines (X and $X^{\prime}$ ), in accordance with the ISO 1563 standard (13).

Dimensional accuracy measurements were performed on the stone models using an optical microscope (STM; Olympus Optical Co Ltd, Japan) with an accuracy of $0.0005 \mathrm{~mm}$. The dimensional accuracy expressed as a percentage (L) was calculated in accordance with ISO 1563 (13) using the equation:

$\mathrm{L}=[(\mathrm{L} 2-\mathrm{L} 1) / \mathrm{L} 1] \times 100$, in which $\mathrm{L} 1$ is the distance between the lines on the matrix and L2 is the

Table 1. Mean values of dimensional accuracy (\%) for the different groups.

\begin{tabular}{|c|c|c|c|c|}
\hline $\begin{array}{l}\text { Alginate } \\
\text { impression } \\
\text { material }\end{array}$ & $\begin{array}{c}\text { No } \\
\text { disinfectant } \\
\text { (control) }\end{array}$ & $\begin{array}{c}2 \% \\
\mathrm{NaOCl}\end{array}$ & $\begin{array}{c}2 \% \\
\mathrm{CHX}\end{array}$ & $\begin{array}{c}0.2 \% \\
\text { Peracetic } \\
\text { acid }\end{array}$ \\
\hline Jeltrate Plus & $\begin{array}{l}100.01 \\
(0.20)\end{array}$ & $\begin{array}{l}100.16 \\
(0.07)\end{array}$ & $\begin{array}{l}100.29 \\
(0.16)\end{array}$ & $\begin{array}{l}100.25 \\
(0.20)\end{array}$ \\
\hline $\begin{array}{l}\text { Cavex } \\
\text { ColorChange }\end{array}$ & $\begin{array}{l}100.09 \\
(0.23)\end{array}$ & $\begin{array}{l}100.05 \\
(0.22)\end{array}$ & $\begin{array}{l}100.17 \\
(0.16)\end{array}$ & $\begin{array}{l}100.08 \\
(0.12)\end{array}$ \\
\hline Hydrogum 5 & $\begin{array}{c}100.20 \\
(0.16)\end{array}$ & $\begin{array}{c}100.04 \\
(0.08)\end{array}$ & $\begin{array}{c}100.06 \\
(0.09)\end{array}$ & $\begin{array}{c}100.09 \\
(0.23)\end{array}$ \\
\hline
\end{tabular}

$\mathrm{NaOCl}$ : sodium hypochlorite. CHX: chlorhexidine digluconate. Standard deviations are provided in parentheses. distance between the lines on the stone models. The dimensional accuracy results were subjected to the Kolmogorov-Smirnov test for normality, and then to two-way ANOVA (material x disinfectant).

\section{RESULTS}

The surface detail reproduction of all alginate impression materials was completely reproduced on the $50 \mu \mathrm{m}$-line regardless of disinfection procedure ( $100 \%$ of the 5 samples of the 12 groups). There was no statistically significant difference in the mean values of dimensional accuracy in combinations among the disinfectant procedures and alginate impression materials $(\mathrm{p}=0.2130)$ or for independent factors (material and disinfectant) (Table 1).

\section{DISCUSSION}

The decontamination of impression materials is essential for the control of cross-infection (7). The effect of alginate impression storage following spraying with disinfectant solution on the dimensional stability of the subsequent stone models has been previously investigated $(8,14)$. The reports vary markedly in their choice of disinfectant concentration and procedure, making it difficult to assess the most appropriate method (7). The most frequently used disinfectants are glutaraldehyde, formaldehyde, alcohol, iodine solution, synthetic phenol, $\mathrm{NaOCl}$ and other chlorinereleasing solutions (5). However, few studies have assessed the interaction between the type of alginate impression material and disinfection with peracetic acid. In the present study, disinfection consisted of a 15 -min treatment with $2 \% \mathrm{NaOCl}, 2 \% \mathrm{CHX}$ or $0.2 \%$ peracetic acid.

It is recommended that the impressions be stored in sealed bags following treatment with glutaraldehyde or $\mathrm{NaOCl}(1,15)$. Glutaraldehyde is considered a high-level disinfectant (16) that should eliminate some spores, the bacillus responsible for tuberculosis, vegetative bacteria, fungi, and viruses. However, the use of glutaraldehyde has been banned in some Brazilian states. Substances containing chlorine, such as $2 \% \mathrm{NaOCl}$, are considered intermediate-level disinfectants that have limited effect on bacterial spores and non-lipid containing viruses, but are effective against tuberculosis bacilli, vegetative bacteria, and most fungi.

$\mathrm{CHX}$ is a cationic bisbiguanide [1,6-di 
(4-chlorophenyl-diguanido) hexane] agent with a broad antibacterial spectrum (Gram-negative and Grampositive), and some virus and antifungal activities (10). It is also biocompatible with oral tissues (10) and has the ability to remain on a surface and be gradually released $(10,17)$. Its excellent properties have motivated its increasing use in dentistry. Moreover, the antimicrobial may be contained in the power/liquid alginate materials (10). However, the response of microorganisms to the chemical agent depends, among others, on the type of microorganism. In a previous study, CHX showed no response on Pseudomonas aeruginosa (Gram negative bacillus), probably because this strain is resistant to CHX (10). Thus, CHX is also considered an intermediate-level disinfectant. Peracetic acid is a combination formed from the chemical reaction of acetic acid $\left(\mathrm{CH}_{3} \mathrm{COOH}\right)$ with an aqueous solution of hydrogen peroxide $\left(\mathrm{H}_{2} \mathrm{O}_{2}\right)$ or by the reaction of tetraacetylethylenediamine with alkaline hydrogen peroxide solution (18). In addition to being a high-level disinfectant, it is also biodegradable and nontoxic.

In the present study, the surface detail reproduction and dimensional accuracy (Table 1) of stone models were not affected by the choice of disinfectant solution or alginate impression material. In a previous study (19), the surface detail reproduction of stone models and dimensional change of 10 alginate products stored in $100 \%$ relative humidity for $2 \mathrm{~h}$ were investigated. Amongst these products, some typical products were sprayed with disinfectant and sealed in storage bags for $2 \mathrm{~h}$ (19). It was found that storage for $2 \mathrm{~h}$ after spraying with either $1 \% \mathrm{NaOCl}$ or $2 \%$ glutaraldehyde did not affect the dimensional change and deformation of stone models obtained from alginate impression, which was characterized by little contraction in $100 \%$ relative humidity (19). However, peracetic acid is a more powerful oxidant agent than chloride and chloride dioxide, causing the rupture of the cell membrane by means of protein denaturing $(18,20)$. Due to its high level of disinfection, peracetic acid would appear to be the solution of choice. However, in a pilot study, solutions containing higher concentrations of peracetic acid caused bubbles in alginate molds.

The cast surfaces of impressions that were rinsed with water and stored in sealed plastic containers at $100 \%$ humidity were better than those that were poured immediately after rinsing $(14,21)$. According to Tan et al. (14), this is due to a decrease in exudates from syneresis (which retard the setting of dental plaster and affect the cast surface) during storage. In the present study, the samples were stored for 15 min during disinfection and no deterioration in detail reproduction was observed.

The alginate impressions were covered with moist gauze during storage. The amount of water absorption varies with disinfectant concentration and type (8). This occurs because water is displaced in response to differences in osmotic pressure between the impression and the disinfectant solution, as well as the chemical action of the disinfectant on the impression $(8,22)$. However, in the present study, stone models produced using Cavex ColorChange, Hydrogum 5 and Jeltrate Plus impressions exhibited no difference with respect to disinfectant solution. The disinfectant solution used by spraying showed no influence on surface detail reproduction or dimensional accuracy after storage. Results similar to those were found in other studies with other disinfectants probably with no immersion of alginate molds $(7,19)$.

Acceptable methods of measuring the dimensional accuracy of casts include measuring calipers $(7,22)$, micrometers (23), dial gauges (24), and measuring microscopes (25). The latter device was used in the present study due to its high accuracy $(0.0005 \mathrm{~mm})$. The largest dimensional deviation between the matrix and stone models was $0.29 \%$ (Jeltrate Plus with $2 \%$ CHX disinfection), which did not differ statistically from the other material/disinfection combinations. Alginate impression materials are typically recommended for prosthetics and orthodontic purposes where the level of accuracy is perceived as less critical (7). However, our results suggest that this impression material has sufficient dimensional stability for other uses as well.

Based on the obtained results, the null hypotheses were accepted, as there were no differences in [1] the surface detail reproduction or [2] dimensional accuracy of stone models produced using any of the alginate impression materials or disinfectant solutions. It may be concluded that there were no differences in surface detail reproduction or dimensional accuracy of stone models regardless of alginate impression material or disinfectant solution used in this study. The disinfectant solutions and alginate materials evaluated in the study are no factors of choice regarding surface detail reproduction and dimensional accuracy of stone models. The highlevel disinfectant peracetic acid would be the material of choice for disinfection. Further studies are required to confirm its effectiveness in disinfection of alginate impression materials. 


\section{RESUMO}

Este estudo comparou a reprodução de detalhes da superfície e alteração dimensional de modelos de gesso obtidos a partir de moldes desinfetados com hipoclorito de sódio $2 \%$, digluconato de clorexidina $2 \%$, ou ácido peracético $0,2 \%$ a modelos confeccionados utilizando moldes que não foram desinfetados com três alginatos (Cavex ColorChange, Hydrogum 5, Jeltrate Plus). Os moldes foram preparados sobre matriz contendo linhas de 20, 50 e $75 \mu \mathrm{m}$ realizado sob pressão com moldeira de metal perfurada. Os moldes foram removidos após a geleificação e desinfetados (utilizando uma das soluções por pulverização, armazenados em frascos fechados durante $15 \mathrm{~min}$ ) ou não desinfetados. Assim, as amostras foram divididas em 12 grupos $(\mathrm{n}=5)$. Os moldes foram preenchidos com gesso dental Durone IV e uma hora após a manipulação do gesso os modelos foram separados da moldeira. A reprodução de detalhes da superfície e a precisão dimensional foram avaliadas usando microscopia óptica na linha $50 \mu \mathrm{m}$ com $25 \mathrm{~mm}$ de comprimento, de acordo com a norma ISO 1563. Os resultados de precisão dimensional (\%) foram submetidos à ANOVA. A linha de $50 \mu \mathrm{m}$ foi completamente reproduzida por todos os alginatos, independentemente do processo de desinfecção. Não houve diferença estatisticamente significativa nos valores médios de precisão dimensional nas combinações entre procedimento de desinfecção e alginato $(\mathrm{p}=0,2130)$, ou para fatores independentes. Soluções desinfetantes e alginatos utilizados neste estudo não são fatores de escolha em relação à reprodução de detalhes da superfície e alteração dimensional de modelos de gesso.

\section{ACKNOWLEDGEMENTS}

The authors wish to thank Ecoper Química for providing the peracetic acid used in this study and Engineer Marcos Blanco Cangiani for his assistance in manufacturing the matrix.

\section{REFERENCES}

1. Infection control recommendations for the dental office and the dental laboratory. Council Dental Materials, Instruments, and Equipment. Council on Dental Practice. Council on on Dental Therapeutics. J Am Dent Assoc 1988;116:241-248.

2. Hiraguchi H, Kaketani M, Hirose H, Yoneyama T. Effect of immersion disinfection of alginate impressions in sodium hypochlorite solution on the dimensional changes of stone models. Dent Mater J 2012;31:280-286.

3. Orsi IA, Andrade VG, Bonato PS, Raimundo LB, Herzog DS, Borie E. Glutaraldehyde release from heat-polymerized acrylic resins after disinfection and chemical and mechanical polishing. Braz Dent J 2011;22:490-496.

4. Kimondollo PM. Guidelines for developing a dental laboratory infection-control protocol. Int J Prosthodont 1992;5:452-456.

5. Carvalhal CI, Mello JA, Sobrinho LC, Correr AB, Sinhoreti MA. Dimensional change of elastomeric materials after immersion in disinfectant solutions for different times. J Contemp Dent Pract 2011;12:252-258.

6. Adabo GL, Zanarotti E, Fonseca RG, Cruz CA. Effect of disinfectant agents on dimensional stability of elastomeric impression materials. J Prosthet Dent 1999;81:621-624.

7. Taylor RL, Wright PS, Maryan C. Disinfection procedures: their effect on the dimensional accuracy and surface quality of irreversible hydrocolloid impression materials and gypsum casts. Dent Mater 2002;18:103-110.

8. Hiraguchi H, Nakagawa H, Wakashima M, Miyanaga K, Sakaguchi $\mathrm{S}$, Nishiyama M. Effect of storage period of alginate impressions following spray with disinfectant solutions on the dimensional accuracy and deformation of stone models. Dent Mater J $2005 ; 24: 36-42$

9. Bergman B, Bergman M, Olsson S. Alginate impression materials, dimensional stability and surface details sharpness following treatment with disinfectant solutions. Swed Dent J 1985;9:255-262.

10. Casemiro LA, Pires-de-Souza FC, Panzeri H, Martins CH, Ito IY. In vitro antimicrobial activity of irreversible hydrocolloid impressions against 12 oral microorganisms. Braz Oral Res 2007;21:323-329.

11. Carlo HL, Fonseca RB, Gonçalves LS, Correr-Sobrinho L, Soares CJ, Sinhoreti MAC. Analysis of filler particle levels and sizes in dental alginates. Mater Res 2010;13:261-264.

12. Craig RG. Review of dental impression materials. Adv Dent Res 1988;2:51-64.

13. ISO 1563 "Dental alginate impression material" Geneva Switzerland, 1990.

14. Tan HK, Hooper PM, Buttar IA, Wolfaardt JF. Effects of disinfecting irreversible hydrocolloid impressions on the resultant gypsum casts: Part III - Dimensional changes. J Prosthet Dent 1993;70:532-537.

15. Hiraguchi $H$, Nakagawa $H$, Kaketani M, Hirose H, Nishiyama M. Effects of disinfection of combined agar/alginate impressions on the dimensional accuracy of stone casts. Dent Mater J 2007;26:457462.

16. Omidbakhsh N. A new peroxide-based flexible endoscopecompatible high-level disinfectant. Am J Infect Control 2006;34:571-577.

17. Ramer MS, Gerhardt DE, McNally K. Accuracy of irreversible hydrocolloid impression material mixed with disinfectant solutions. J Prosthodont 1993;2:156-158.

18. Fernandes FH, Orsi IA, Villabona CA. Effects of the peracetic acid and sodium hypochlorite on the color stability and surface roughness of the denture base acrylic resins polymerised by microwave and water bath methods. Gerodontology 2012 [Epub ahead of print. DOI: 10.1111/j.1741-2358.2012.00640.x.]

19. Hiraguchi H, Nakagawa H, Uchida H, Tanabe N. Effect of storage of alginate impressions following spray with disinfectant solutions on the dimensional accuracy and deformation of stone models. J J Dent Mater 2004;23:8-15.

20. Rutala WA, Weber DJ. Clinical effectiveness of low-temperature sterilization technologies. Infect Control Hosp Epidemiol 1998;19:798-804.

21. Hiraguchi H, Nakagawa H, Wakashima M, Miyanaga K, Saigo M, Nishiyama M. Effects of disinfecting alginate impressions on the scratch hardness of stone models. Dent Mater J 2006;25:172-176.

22. Woodward JD, Morris JC, Khan Z. Accuracy of stone casts produced by perforated trays and nonperforated trays. J Prosthet Dent 1985;53:347-350

23. Rueggeberg FA, Beall FE, Kelly MT, Schuster GS. Sodium hypochlorite disinfection of irreversible hydrocolloid impression material. J Prosthet Dent 1992;67:628-631.

24. Millstein PL. Determining the accuracy of gypsum casts made from type IV dental stone. J Oral Rehabil 1992;19:239-243.

25. Hilton TJ, Schwartz RS, Bradley DV Jr. Immersion disinfection of irreversible hydrocolloid impressions. Part 2: Effects on gypsum casts. Int J Prosthodont 1994;7:424-433.

Received June 1, 2012

Accepted September 25, 2012 